CLINICAL STUDY

\title{
Variable pathological and clinical features of a large Brazilian family harboring a mutation in the aryl hydrocarbon receptor- interacting protein gene
}

\author{
Luciana A Naves ${ }^{1}$, Adrian F Daly ${ }^{2}$, Jean-François Vanbellinghen ${ }^{3}$, Luiz A Casulari ${ }^{1}$, Cristina Spilioti ${ }^{4}$, Albino \\ $V_{\text {V Magalhães }}^{5}$, Monalisa F Azevedo ${ }^{1}$, Leonardo A Giacomini ${ }^{1}$, Paula P Nascimento ${ }^{1}$, Rousielysson O Nunes ${ }^{6}$, \\ Joao W C Rosa ${ }^{1}$, Marie-Lise Jaffrain-Rea ${ }^{4}$, Vincent Bours ${ }^{3}$ and Albert Beckers ${ }^{2}$ \\ ${ }^{1}$ Department of Endocrinology, Internal Medicine, University of Brasilia, Brasilia DF, Brazil, Departments of ${ }^{2}$ Endocrinology and ${ }^{3}$ Molecular Genetics, \\ Centre Hospitalier Universitaire de Liège, University of Liège, 4000 Liège, Belgium, ${ }^{4}$ Department of Experimental Medicine, University of L'Aquila, 67100 \\ L'Aquila and Neuromed, Istituto di Ricovero e Cura a Carattere Scientifico, 86077 Pozzili, Italy, ${ }^{5}$ Department of Pathology, University of Brasilia, Brasilia \\ DF, Brazil and ${ }^{6}$ Laboratory Sabin, Brasília DF, Brazil \\ (Correspondence should be addressed to L A Naves; Email: lunaves@unb.br)
}

\begin{abstract}
Background: Germline aryl hydrocarbon receptor-interacting protein (AIP) mutations occur in 15\% of familial isolated pituitary adenoma (FIPA) cases. To date, studies have focused on the identification of such mutations in large international cohorts. Detailed genetic and clinical studies within AIP mutation-positive families have been limited.

Aim: To undertake a comprehensive study of a large Brazilian FIPA kindred with an E174 frameshift (E174fs) AIP mutation to assess clinical, hormonal, and radiological features in mutation carriers.

Methods: The kindred included 122 subjects across six generations; all underwent clinical examination. Genetic studies were performed to identify E174fs mutation carriers. E174fs-positive subjects underwent magnetic resonance imaging (MRI) and hormonal assessments.

Results: Of the ten germline AIP mutation carriers, three had pituitary tumors, while seven were asymptomatic carriers. Three patients with pituitary tumors showed variability in terms of tumor phenotype (two with acromegaly, one with prolactinoma, or mixed prolactin/GH-secreting tumor) and age at diagnosis; both patients with acromegaly had poor responses to octreotide. Tumor AIP immunohistochemistry from the operated patient showed decreased expression when compared with normal tissue. Two adult subjects with normal MRI had elevated IGF-I in the absence of other causes. A 2-year-old child with the E174fs mutation and a normal MRI had premature thelarche, ovarian development, and advanced bone age in the absence of other underlying causes.

Conclusions: The penetrance of pituitary tumors in AIP mutation-positive adult subjects was $33.3 \%$, while clinical/hormonal features were variable. The features noted in AIP-mutation carriers in this kindred suggest that clinical characteristics of such carriers may extend beyond pituitary tumors.
\end{abstract}

European Journal of Endocrinology 157 383-391

\section{Introduction}

Pituitary adenomas comprise $\sim 10 \%$ of intracranial tumors and recent estimates suggest that clinically apparent pituitary adenomas have a prevalence of $\sim 1$ in 1000 individuals $(1,2)$. The pathophysiology of pituitary adenomas is complex and a large number of genetic and molecular defects have been identified. The most relevant among these include mutations in the Gs $\alpha$ and PTTG genes (3, 4). In general, pituitary adenomas occur sporadically and the occurrence of pituitary adenomas in a familial or hereditary setting is rare; it is currently estimated that about $5 \%$ of pituitary adenomas are familial as reviewed by Beckers \& Daly in this issue (5). Multiple endocrine neoplasia-I (MEN-I), caused by mutations in the MEN-I gene on chromosome $11 \mathrm{q} 13$ and Carney complex (CNC), due to mutations in the PRKAR1A gene on chromosome $17 \mathrm{q} 22$, are well recognized to cause familial pituitary adenomas $(6,7)$. Isolated familial somatotropinoma (IFS) is a rare condition separate from MEN-I and CNC that has been reported in over 50 families $(8,9)$. Familial isolated pituitary adenoma (FIPA), which comprises pituitary adenomas of all phenotypes occurring in a family setting, has been characterized in more than 90 families over the past decade (9). Vierimaa et al. reported that mutations in the aryl hydrocarbon receptor (AhR)interacting protein $(A I P)$ gene were associated with non-MEN-I, non-CNC familial pituitary adenomas (10). Recently, Daly et al. reported that AIP mutations occur 
in $15 \%$ of FIPA families (50\% of those with IFS), while tumors in patients with AIP mutations are larger and are diagnosed at a significantly younger age than in FIPA patients without AIP mutations or in sporadic tumors (11). Current evidence suggests that the pituitary tumor phenotype of affected patients is heterogeneous within and among families (10-12). While somatotropinomas are the predominant finding in association with AIP mutations, somatolactotrope tumors, prolactinomas, and non-secreting adenomas have all been described in the FIPA setting (11); a patient with Cushing's disease was also reported to have an AIP mutation (12).

The studies mentioned above have focused on identifying mutations in AIP in large international cohorts of patients with sporadic or familial pituitary tumors. While data on AIP status have been reported retrospectively in previously described IFS families $(13,14)$, neither these studies nor the international cohort reports have presented detailed clinical, genetic, hormonal, and pathological analysis of disease status in families with AIP mutations. To this end, we undertook a comprehensive study of 122 members of a Brazilian FIPA kindred with an AIP mutation in order to determine the clinical status of mutation carriers, tumor characteristics (including immunohistochemistry), and disease penetrance.

\section{Methods}

\section{Molecular genetic studies}

Genomic DNA was isolated from the peripheral blood of participating subjects. We used ensembl sequences ENST00000279146, ENSG00000110711, and ENSP00000279146 to determine the sequence and structure of AIP. The primers used for the analysis of the AIP exonic and flanking intronic sequences are as reported by Vierimaa et al. (10). For the PCR, each $25 \mu \mathrm{l}$ mixture contained $150 \mathrm{ng}$ genomic DNA, $1 \mu \mathrm{M}$ of each primer, $1.5 \mathrm{mM} \mathrm{MgCl}_{2}, 10 \mathrm{mM}$ Tris-HCl buffer (pH 8.3), $200 \mu \mathrm{M}$ dNTPs, and $1.25 \mathrm{U}$ FastStart Taq polymerase (Roche). PCR conditions were as follows: $95^{\circ} \mathrm{C}$ for $10 \mathrm{~min}$ followed by 30 cycles of $30 \mathrm{~s}$ at $95^{\circ} \mathrm{C}$, $30 \mathrm{~s}$ at $68{ }^{\circ} \mathrm{C}$, and $20 \mathrm{~s}$ at $72{ }^{\circ} \mathrm{C}$. PCR products were sequenced using ABI3100 and BigDye Terminator v3.1 technology (Applied Biosystems, Lennik, Belgium).

An E174 frameshift (E174fsi; c.517_521delGAAGA; GenBank accession number EF066503) AIP mutation was noted in three members of the family with pituitary adenomas; we have previously showed that the E174fs mutation is not present in DNA from screened normal volunteers (11).

The purpose of the study was explained and a comprehensive series of interviews with members of the kindred at various sites across Brazil were conducted to construct a complete genealogical tree of 122 members across six generations. The kindred was non-consanguineous. All consenting subjects provided a full medical history and underwent a clinical examination; these results were scrutinized for disease expression or patterns of disease. Beginning with the oldest living generations of the kindred, genetic studies were performed (after obtaining informed consent) to assess carrier status for the E174fs AIP mutation. In mutation carriers, all relatives underwent molecular genetic studies for AIP carrier status. Genetic studies were performed only in those subjects that were possible carriers of the E174fs AIP mutation based on the genetic status of their parents. AIP mutation carriers underwent further study involving non-enhanced magnetic resonance imaging (MRI) of the brain ( $2 \mathrm{~mm}$ cuts), static hormonal tests of the thyroid axis, cortisol, growth hormone $(\mathrm{GH})$, insulin-like growth factor-I (IGF-I), and prolactin (PRL). All consenting AIP mutation carriers underwent a 2-h oral glucose tolerance test (OGTT) with measurement of GH.

\section{Immunohistochemistry}

For determining the AIP immunohistochemistry of pituitary tumor tissue from one operated patient, paraffinized pituitary tumor sections were dewaxed in xylene and rehydrated using a descending ethanol series. Antigen retrieval was performed by microwave boiling in citrate buffer $\mathrm{pH} 6.0$ for two periods of $5 \mathrm{~min}$ and one period of $3 \mathrm{~min}$. Immunohistochemistry was performed using a mouse anti-human AIP mAb at a 1:500 dilution (Novus Biological, DBA Italia s.r.l, Segrate, Italy) and a multilink biotinylated antibody and the avidin-biotin peroxidase system according to the manufacturer's instructions (LSAB + kit, DAKO Cytomation, Milan, Italy). For hormonal and tumor marker immunohistochemistry using the streptavidinbiotin system, the following dilutions of antibodies were employed, anti-GH (polyclonal 1:2000), anti-PRL (polyclonal 1:2000), p-53 (DO7 1:100), Ki-67 (Mib 1 1:100), and c-erb B2 (oncoprotein C 1:400). Reactions were developed with diaminobenzidine and counterstained with hematoxylin.

The study was conducted in accordance with the guidelines of the Declaration of Helsinki and the genetic analysis was approved by the Ethics Committee of the University of Liège. All subjects or guardians provided informed written consent for the investigations performed.

\section{Results \\ Clinical features}

Case 1 The index case, a male presented in 1997 at 17 years of age with a 3-year history of excessive linear growth $(188 \mathrm{~cm}$ at presentation; mother's height 
$154 \mathrm{~cm}$, father's height $160 \mathrm{~cm}$ ), arthralgia, hyperhidrosis, weakness, headaches, and visual field impairment. On examination, the patient exhibited physical features typical of acromegaly, with soft tissue swelling, prognathism, and enlarged extremities (shoe size 52). MRI showed a pituitary macroadenoma measuring $36 \times 45 \times$ $36 \mathrm{~mm}$ with compression of the optic chiasma and bilateral cavernous sinus invasion (Fig. 1a). Basal GH was $51 \mathrm{ng} / \mathrm{ml}$ and no suppression was seen during an OGTT; the associated IGF-I level was $778 \mathrm{ng} / \mathrm{dl}$ (Table 1). The patient underwent transsphenoidal surgery in 1998, which reduced hormonal hypersecretion and improved vision. GH and IGF-I were elevated postoperatively and radiotherapy was performed in late 1998. Subcutaneous intermittent octreotide $(300 \mu \mathrm{g} /$ day $)$ was initiated but tumor regrowth occurred by 2000. Despite increasing medical therapy to octreotide LAR $30 \mathrm{mg} / \mathrm{month}$ and cabergoline $2.0 \mathrm{~g} /$ week, the disease remained active and the patient gained $5 \mathrm{~cm}$ in height from 1998 to 2003 . Late radiotherapy effects were seen from 2003 onwards with a decrease in IGF-I (although they remain elevated), and hypopituitarism (thyrotrope, corticotrope, and gonadotrope axes) was diagnosed in 2006. MRI followup in 2006 showed an empty sella.

Case 2 In 2002, the 25-year-old sister of the index case presented with secondary amenorrhea, galactorrhea, and headaches. On physical examination, there was mild soft-tissue swelling of the face and hands, and no visual field impairment. Hormonal assessment showed elevated levels of PRL (148.5 ng/ml) and an increased IGF-I (489 ng/dl). Basal GH secretion was $0.68 \mathrm{ng} / \mathrm{ml}$, which decreased but did not fully suppress (nadir level $0.38 \mathrm{ng} / \mathrm{ml}$ ) during an OGTT. A 24-h GH profile showed a mean GH concentration of $1.84 \mathrm{ng} / \mathrm{ml}$. An MRI revealed a pituitary adenoma of $9 \times 8 \mathrm{~mm}$ in maximum diameter (Fig. 1b). The patient was treated with dopamine agonists, with adequate hormonal control being achieved with a cabergoline dose of $2 \mathrm{~g} /$ week. Subsequently, menses returned and headaches lessened, but the patient has remained infertile despite normal gonadal function. During follow-up, IGF-I levels were noted to be intermittently above the normal range for age and sex. The lack of absolute GH suppression (a)

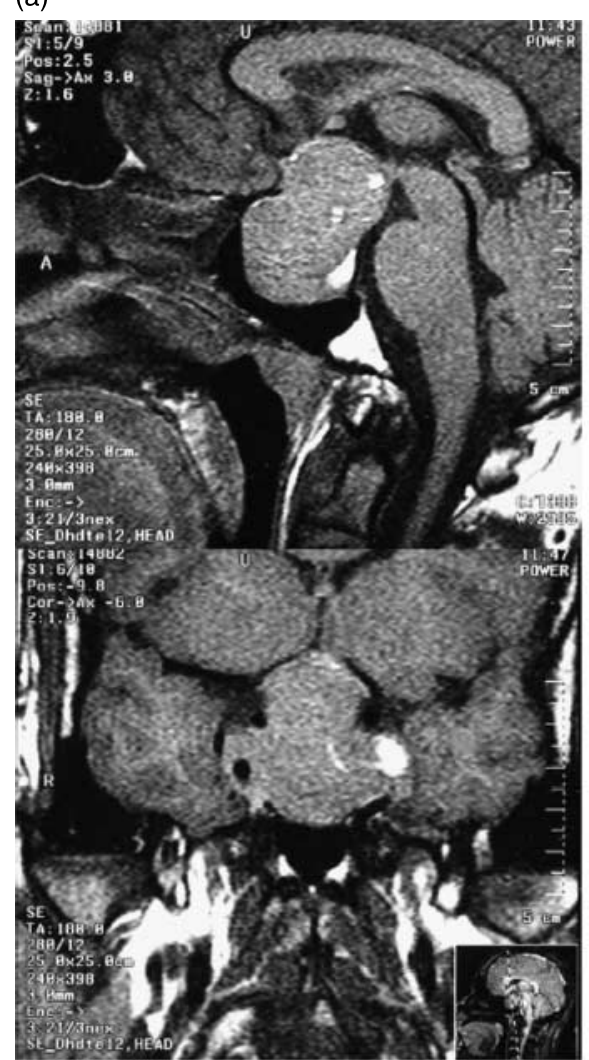

(b)

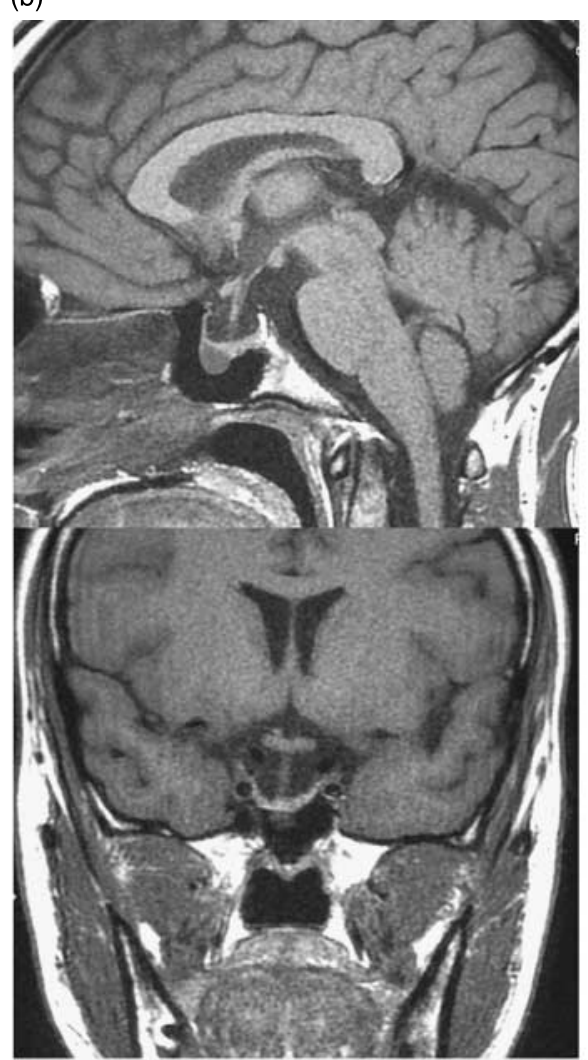

(c)

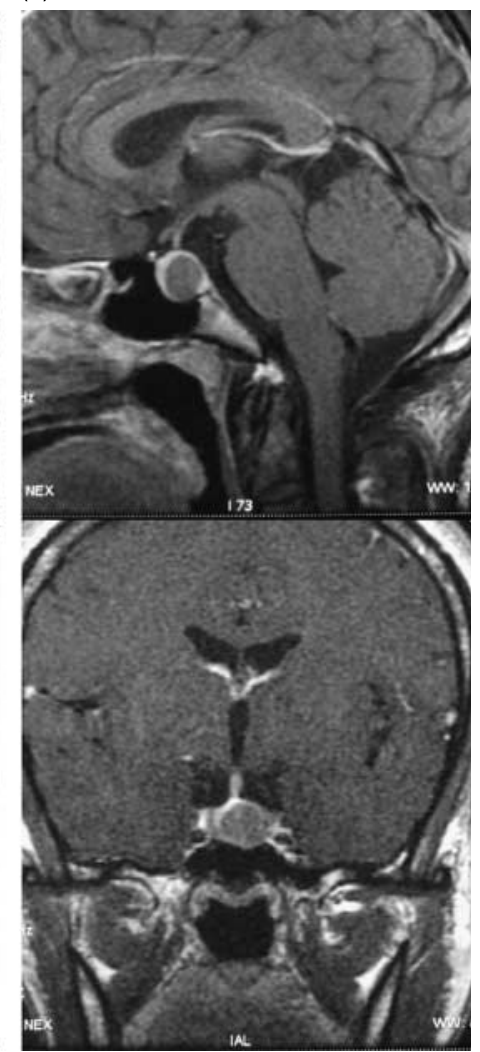

Figure 1 Coronal and sagittal T1-weighted MRI taken at diagnosis in three family members with pituitary tumors in association with an E174 frameshift AIP mutation. (a) The index case presented at 17 years of age with a large invasive pituitary macroadenoma, (b) his sister presented aged 25 with a $9 \times 8 \mathrm{~mm}$ pituitary adenoma, and (c) the aunt of the two other patients presented at age 35 with a non-invasive pituitary macroadenoma. For (a), $3 \mathrm{~mm}$ cuts were used and for (b) and (c), $2 \mathrm{~mm}$ cuts were used. 


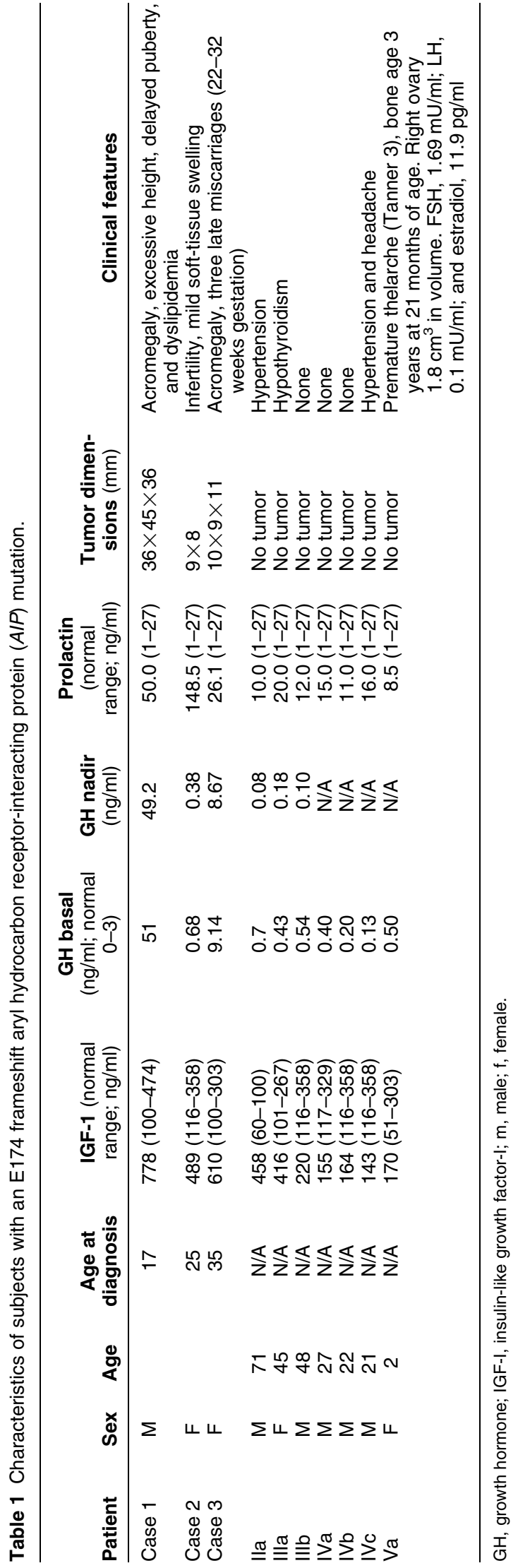

combined with the marked IGF-I elevation and hyperprolactinemia suggest that a somatolactotrope adenoma may be present in this case.

Case 3 The 35-year-old maternal aunt of cases 1 and 2 was first evaluated in 2005 on the advice of her nephew (case 1). She had a 10-year history of worsening arthralgia, hyperhidrosis, weakness, and headaches. Her past medical history was relevant for three pregnancies that all ended in late miscarriages at 20, 25, and 30 weeks' gestation; no relevant structural or pathological obstetric causes were found. Clinical examination revealed typical facial features of acromegaly with prognathism and pronounced soft-tissue swelling of the lips and nose. No visual abnormalities were found and the patient was of normal stature. Her basal GH was elevated at $9.14 \mathrm{ng} / \mathrm{ml}$, which failed to suppress during an OGTT (nadir GH level $8.67 \mathrm{ng} / \mathrm{ml}$ ). Her IGF-I was also elevated at $610 \mathrm{ng} / \mathrm{ml}$ and her PRL was at $26.1 \mathrm{ng} / \mathrm{ml}$. No other hormonal abnormalities were present at diagnosis. An MRI revealed a pituitary macroadenoma measuring $10 \times 9 \times 11 \mathrm{~mm}$ without evidence of extrasellar extension or invasion (Fig. 1c). Following 7 months of treatment with octreotide LAR at a dose of $30 \mathrm{mg} / \mathrm{month}$, IGF-I decreased but remained elevated at $378 \mathrm{ng} / \mathrm{ml}$ and no tumor shrinkage was seen on MRI.

\section{Characteristics of mutation carriers}

The genealogical tree for the family comprised 122 individuals and genetic studies identified seven additional asymptomatic carriers of the E174fs mutation across six generations; the mutation was traced to the maternal grandfather of the index case (Fig. 2). In the three cases with pituitary tumors, an E174fs mutation in AIP was noted. The penetrance of pituitary tumors among adult mutation carriers $(n=9)$ in this FIPA family was $33.3 \%$.

In the seven E174fs mutation carriers, clinical, hormonal, and MRI studies were performed. No pituitary adenomas were diagnosed in these seven individuals. Four mutation carriers were entirely hormonally and clinically normal. Two asymptomatic mutation carriers were found to have IGF-I levels above the normal range for their age and sex. In subject IIa, the 71-year-old grandfather of the index case, an IGF-I of $458 \mathrm{ng} / \mathrm{ml}$ (normal range for age and sex: $60-100 \mathrm{ng} / \mathrm{ml}$ ) was noted, while subject IIIa, the 45-year-old mother of the cases 1 and 2, had an IGF-I of $416 \mathrm{ng} / \mathrm{ml}$ (normal range: 101-267 ng/ml). The elevated IGF-I levels were not associated with clinical signs/symptoms and no concomitant conditions associated with elevated IGF-I were present. In both cases an OGTT was normal (Table 1). 


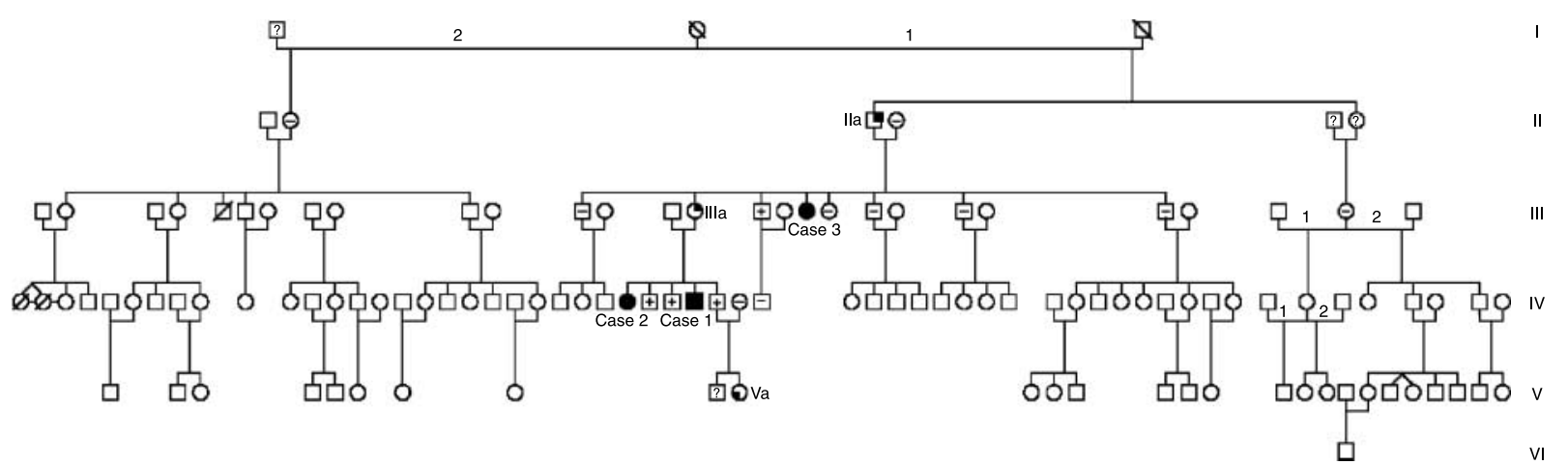

Figure 2 Genealogical tree of six generations of a family with an E174 frameshift AIP mutation. All members of the kindred underwent medical assessments for signs and symptoms of pituitary or other diseases and the full genealogy was mapped. Consanguinity was ruled out. Potential routes of inheritance of the mutated $A I P$ were traced and molecular genetic studies were undertaken in targeted individuals to assess whether the mutation had been passed to later generations. AIP mutation carriers underwent hormonal and radiological studies, and all relatives of carriers were genotyped. Subjects marked with filled (black) symbols were the mutation-positive individuals with pituitary tumors (cases 1, 2, and 3). Subjects marked with $(+)$ were mutation carriers without clinical, hormonal, or radiological evidence of disease. Subjects marked with $(-)$ were genotyped as being wild-type homozygotes for AIP. Subjects marked with (?) declined genetic analysis but were free from clinical evidence of pituitary or other illnesses. AIP mutation carriers with elevated IGF-I levels (subjects Ila and IIla) are shown (filled (black) upper right quadrant symbol); an infant girl with the E174fs AIP mutation and premature thelarche, ovarian enlargement, and advanced bone age (subject $\mathrm{Va}$ ) is shown (filled lower left quadrant symbol). Multiple partners/couplings are numbered separately. Apart from the subjects noted above, clinical history and examination were normal in all other members of the kindred.

A female infant (Va), a mutation carrier, was noted to have premature thelarche at 1 year of age. After 1 year of follow-up, breast development continued and reached Tanner stage 3. At 23 months of age, she had a bone age of 3 years. Pelvic ultrasound showed an enlarged right ovary $\left(1.8 \mathrm{~cm}^{3}\right)$ with five visible follicles, while the left ovary had a normal volume $\left(0.7 \mathrm{~cm}^{3}\right)$ and contained three follicles; the uterus was normal in appearance and volume $\left(0.8 \mathrm{~cm}^{3}\right)$. Hormonal evaluations showed a follicle-stimulating hormone level of $1.3 \mathrm{mU} / \mathrm{ml}$ (normal $<1.6 \mathrm{mU} / \mathrm{ml}$ ), a luteinizing hormone level of $0.1 \mathrm{mU} / \mathrm{ml}$ (normal $<0.6 \mathrm{mU} / \mathrm{ml}$ ), an estradiol level of $11.9 \mathrm{pg} / \mathrm{ml}$ (normal $<8 \mathrm{pg} / \mathrm{ml}$ ), and a PRL level of $8.5 \mathrm{ng} / \mathrm{ml}$ (normal range $0.33-27.3 \mathrm{ng} / \mathrm{ml}$ ). Gonadotrophinreleasing hormone and OGTT tests were declined by the parents at this time. An MRI revealed no pituitary, hypothalamic, or other abnormalities. Clinical examination showed no features associated with known causes of precocious puberty (e.g. no visible café au lait spots suggestive of McCune-Albright syndrome) at last follow-up in June 2007.

Further clinical evaluation of all ten individuals bearing E174fs mutations revealed no symptomatology or features suggestive of other potential AIP mutationassociated disease in other tissues.

\section{Tumor immunohistochemistry}

Only one of the three subjects with pituitary tumors underwent surgery. Immunohistochemistry of the tumor tissue from this patient showed strongly positive staining ( $>50 \%$ of positive cells) for GH and PRL. Interestingly, strong c-erb staining was also seen (Fig. 3a), while the tumor was negative for Ki-67 and p53. AIP immunohistochemistry results are shown in Fig. 3b. Staining for (a) C-erb

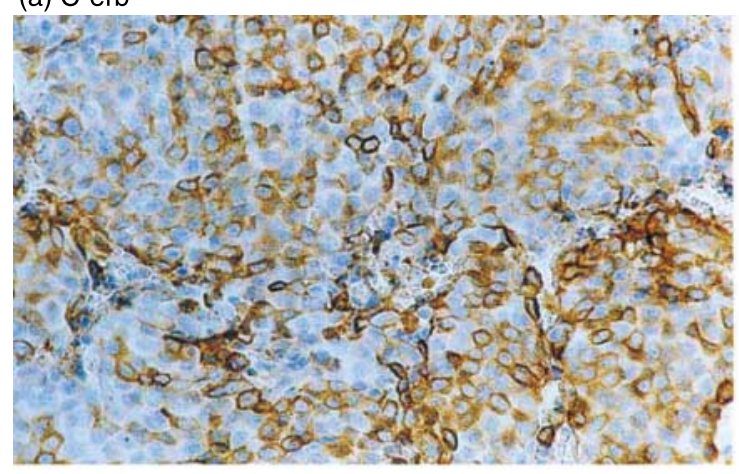

(b) AIP

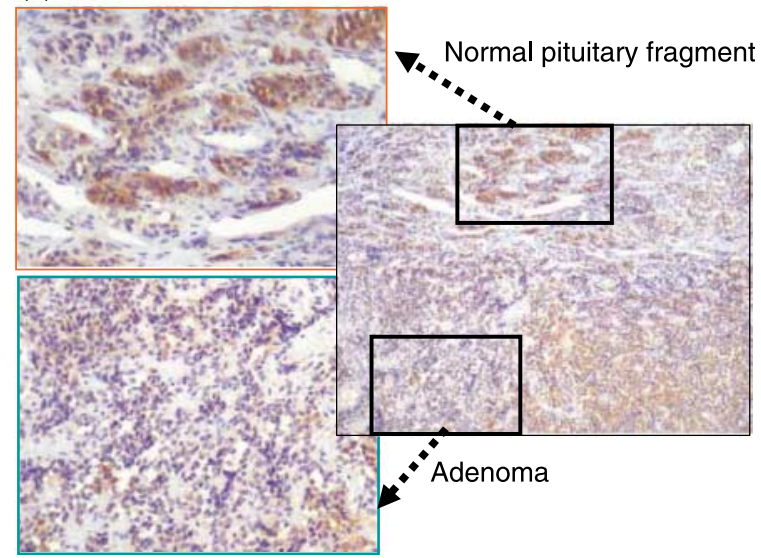

Figure $3 \mathrm{Immunohistochemistry} \mathrm{of} \mathrm{pituitary} \mathrm{tumor} \mathrm{from} \mathrm{index} \mathrm{case.}$ (a) The tumor, which stained strongly positive for growth hormone and prolactin (not shown) also had strong positive staining for c-erb. (b) Immunohistochemistry of the pituitary tumor for AIP, showing the reduced AIP staining seen in a region of tumor when compared with a section of normal pituitary. 
AIP in adenomatous tissue was heterogeneous but markedly lower than in the adjacent normal pituitary fragment, where intense cytoplasmic staining was noted in most cells. Faint nuclear staining was observed only in a minority of normal pituitary cells.

\section{Discussion}

The occurrence of pituitary tumors in a familial setting accounts for $5 \%$ of pituitary tumors (5); most are due to MEN-I, while CNC occurs very rarely (15). Recently, acromegaly and MEN-I-like features were reported in one family with a CDKN1B mutation, although such mutations appear very rare (16-18). Germline mutations of AIP occur in familial and sporadic pituitary adenomas, although the latter are very infrequent. In FIPA, AIP mutations account for half of all cases of IFS, while $85 \%$ of families are negative for AIP mutations indicating that other genes may be involved in its pathogenesis (11).

The current report concerns a family that has not been described in detail in the literature to date. With the advent of molecular genetic testing for AIP, it was possible to undertake an extensive prospective assessment of the frequency of the occurrence of the E174fs mutation across multiple generations. Overall, we found that ten individuals bore the E174fs mutation, of which three had a diagnosis of an isolated pituitary adenoma. As one of the mutation carriers was an infant and it is usual to express penetrance at a given age, we have elected to calculate penetrance of pituitary tumors among adult mutation carriers in this family. Thus, the penetrance of pituitary tumors in this FIPA family was $33.3 \%$ (3/9). This penetrance figure falls within the range of 25 to $>85 \%$ seen in other FIPA families with AIP mutations (Beckers \& Daly unpublished data). A similarly wide range for penetrance has also been reported recently by another international collaborative group (20). Taken together, these data suggest that the occurrence of pituitary tumors in patients with AIP mutations is not a low-penetrance condition.

The phenotypic characteristics of the patients with tumors in this family are varied, which appears to be a feature of FIPA in general and of those with AIP mutations in particular. On clinical findings, one patient had prolactinoma and two had acromegaly. However, hormonal data indicate that the patient with the prolactinoma also had intermittently elevated IGF-I secretion, suggesting the presence of a somatolactotrope tumor. The index case with acromegaly also had combined GH and PRL hypersecretion and his tumor stained strongly positive for both hormones. Although both cases 1 and 3 had acromegaly, they differed significantly from each other. Case 1 had much more aggressive disease in terms of an early age at onset (17 vs 35 years), a larger tumor size and much higher basal levels of GH secretion. Case 3 decided not to undergo surgery at this time; therefore, it was not possible to investigate pathological (immunohistochemical) differences between the GH-secreting tumors in both cases. Notably, both patients with acromegaly had poor responses to octreotide therapy and required combination treatment with a somatostatin analog and a dopamine agonist. The underlying reason for this relative octreotide resistance is unexplained, as is the more general issue of why the same AIP mutation would cause different pituitary tumor phenotypes in three closely related individuals.

AIP immunohistochemistry has been previously applied to pituitary tumor samples, although there are few data regarding patterns of staining in normal tissue and in different types of pituitary tumors. In the present study, we used an mAb against human AIP, which revealed cytoplasmic staining in only $30 \%$ of tumor cells when compared with stronger and diffuse expression in the adjacent normal pituitary fragment. This is in keeping with the potential loss of expression of AIP protein in the tumor tissue; however, results on loss of heterozygosity for AIP in the paraffin tumor sample were equivocal. Indeed, it is not known precisely how the E174fs mutation affects AIP protein expression. The mutation would predict a series of incorrect amino acids after position 174, followed by a premature stop codon. Such a mutation would abrogate the expression of the third tetratricopeptide repeat domain (TPR) and carboxy-terminal residues that are known to be crucial for interactions of AIP with the AhR and the co-chaperone molecule heat shock protein 90 (hsp90) (11). Indeed, many of the mutations reported to date predict protein changes that would affect the third TPR domain and the carboxy terminal of AIP (10-14, 19). In vitro expression studies will be useful in helping to determine whether the E174fs mutation is expressed as protein or targeted for destruction via nonsense-mediated mRNA decay or other pathways.

Detailed clinical and laboratory studies of the family revealed no consistent features that were indicative of potential AIP-related disease in other tissues, although some endocrine findings are worth highlighting. In two mutation carriers with normal MRI scans, elevated levels of IGF-I were seen in the absence of abnormal GH secretion on basal or strict dynamic testing. Additionally, case 2 showed intermittent elevations in IGF-I without abnormal GH secretion over the course of the follow-up of her prolactinoma. Other causes of increased IGF-I were ruled out in these cases, which suggests that such elevations might be related to their AIP mutation status, although a mechanistic explanation remains difficult. It is not known whether hormonal abnormalities could occur due to nontumoral pituitary hyperplasia in the setting of AIP mutations, as frequently occurs in the pituitaries of patients with $\mathrm{CNC}$ and McCune-Albright syndrome $(21,22)$. Taken together with the differences in pituitary tumor characteristics among the three cases in this family, this clinical picture suggests wide variability in disease expression among AIP mutation 
carriers. An explanation for this is lacking at this time, although the effects of additional random somatic mutations in the pituitary or elsewhere or the modulating actions of other genes (normal or mutated) must be considered.

Environmental factors are another important area of great relevance to discussions of AIP and its potential role in endocrine pathology. Current understanding of the role played by AIP in pituitary cell function is still relatively scanty. AIP has been studied extensively in toxicology, where the effects of AIP in modulating the activity of its receptor, AhR - the dioxin receptor - have received a great deal of scrutiny. However, other effects of AIP on cellular activity have been noted that may be equally relevant to tumorigenic potential. The phosphodiesterases, PDE4A5 and PDE2A, survivin, and translocase of outer mitochondrial membrane 20 (TOM20) are all defined targets for AIP and could undergo dysregulation in the setting of AIP mutations, potentially leading to enhanced cell growth and survival (23-27). Fundamental work on the role of AIP mutations in abnormally modulating cell signaling remains to be performed, and the pathway by which pituitary tumors occur in patients with germline AIP mutations remains speculative.

In terms of the potential involvement of mutated AIP in the pathogenesis of the premature thelarche and abnormal ovarian/bone development in subject Va, AhR-related pathways are known to be involved in gonadotropic axis development $(28,29)$. AhR-mediated gene transcription is modulated via direct recruitment of estrogen receptor- $\alpha$, which links estradiol activity to AhRdioxin-mediated signaling $(30,31)$. This and other associated pathways (e.g. via hsp70 $(32,33))$ are thought to play an important role in the physiology of sexual development at a cellular level in the pituitary. Exposure to dioxin and other environmental toxins during embryonic development can have estrogenic effects, leading to alterations in cellular signaling, biochemical activity, and reproductive function (34-36). Alterations in the AhR pathway are associated with reproductive disorders in animal models (37) and even in humans (38, 39). Intriguingly, animal data suggest that a connection may exist among environmental estrogenic disruptors, AhR pathway signaling and expression of GH, and PRL mRNA in the pituitary, an effect that may be modulated at the level of Pit1 (40-42). While no definitive link between AIP status and the clinical phenotype of subject Va can be made, it is worth considering given the overlaps between AhR pathways, early life hormonal exposure, and subsequent reproductive physiology (43). There was no known history of abnormal estrogenic exposure in the child while in utero or subsequently and no pathological changes of the pituitary or hypothalamus were apparent on MRI. Ongoing follow-up will assess whether the breast, ovarian, and bone changes progress and if abnormalities of the gonadotropic axis become apparent.

In conclusion, this is the first study to examine in depth the clinical, hormonal, and radiological features of a large FIPA kindred with three patients with pituitary adenomas (acromegaly and prolactinoma) associated with mutations in AIP. Among seven asymptomatic mutation carriers, elevations in IGF-I were seen in two adult individuals, while an infant girl presented a progressing pattern of sexual precocity. These results suggest that the same AIP mutation can be associated with a variable phenotype of pituitary tumors among related family members (as suggested previously (11)) and raises the possibility of the involvement of non-tumoral pituitary pathology in mutation carriers. The field of AIP research in the setting of pituitary endocrinology is at an early stage and fundamental data on mutated AIP protein expression and function from in vitro and animal studies is lacking at this time. Before firm conclusions can be drawn regarding clinical disease characteristics related to AIP mutations, the analysis of data from larger cohorts of affected patients will be required.

\section{Acknowledgements}

The authors would like to acknowledge the staff of the Laboratório Sabin, Brasília, Brazil, for undertaking hormonal studies.

\section{References}

1 Daly AF, Rixhon M, Adam C, Dempegioti A, Tichomirowa MA \& Beckers A. High prevalence of pituitary adenomas: a crosssectional study in the province of Liège, Belgium. Journal of Clinical Endocrinology and Metabolism 200691 4769-4775.

2 Davis JR, Farrell WE \& Clayton RN. Pituitary tumours. Reproduction $2001121363-371$.

3 Barlier A, Gunz G, Zamora AJ, Morange-Ramos I, FigarellaBranger D, Dufour H, Enjalbert A \& Jaquet P. Prognostic and therapeutic consequences of Gs alpha mutations in somatotroph adenomas. Journal of Clinical Endocrinology and Metabolism 1998 83 1604-1610.

4 Pei L \& Melmed S. Isolation and characterization of a pituitary tumor-transforming gene (PTTG). Molecular Endocrinology 1997 11 433-441.

5 Beckers A \& Daly AF. The clinical, pathological, and genetic features of familial isolated pituitary adenomas. European Journal of Endocrinology 2007157 371-382.

6 Zhuang Z, Ezzat SZ, Vortmeyer AO, Weil R, Oldfield EH, Park WS, Pack S, Huang S, Agarwal SK, Guru SC, Manickam P, Debelenko LV, Kester MB, Olufemi SE, Heppner C, Crabtree JS, Burns AL, Spiegel AM, Marx SJ, Chandrasekharappa SC, Collins FS, Emmert-Buck MR, Liotta LA, Asa SL \& Lubensky IA. Mutations of the MEN1 tumor suppressor gene in pituitary tumors. Cancer Research 199757 5446-5451.

7 Kirschner LS, Sandrini F, Monbo J, Lin JP, Carney JA \& Stratakis CA. Genetic heterogeneity and spectrum of mutations of the PPKAR1A gene in patients with the Carney complex. Human Molecular Genetics 20009 3037-3046.

8 Frohman LA \& Eguchi K. Familial acromegaly. Growth Hormone and IGF Research 200414 S90-S96.

9 Daly AF, Jaffrain-Rea ML, Ciccarelli A, Valdes-Socin H, Rohmer V, Tamburrano G, Borson-Chazot C, Estour B, Ciccarelli E, Brue T, Ferolla P, Emy P, Colao A, De Menis E, Lecomte P, Penfornis F, Delemer B, Bertherat J, Wemeau JL, De Herder W, Archambeaud F, 
Stevenaert A, Calender A, Murat A, Cavagnini F \& Beckers A. Clinical characterization of familial isolated pituitary adenomas. Journal of Clinical Endocrinology and Metabolism 200691 3316-3323.

10 Vierimaa O, Georgitsi M, Lehtonen R, Vahteristo P, Kokko A, Raitila A, Tuppurainen K, Ebeling TM, Salmela PI, Paschke R, Gundogdu S, De Menis E, Makinen MJ, Launonen V, Karhu A \& Aaltonen LA. Pituitary adenoma predisposition caused by germline mutations in the AIP gene. Science 2006312 1228-1230.

11 Daly AF, Vanbellinghen JF, Khoo SK, Jaffrain-Rea ML, Naves LA, Guitelman MA, Murat A, Emy P, Gimenez-Roqueplo AP, Tamburrano G, Raverot G, Barlier A, De Herder W, Penfornis A, Ciccarelli E, Estour B, Lecomte P, Gatta B, Chabre O, Sabate MI, Bertagna X, Garcia Basavilbaso N, Stalldecker G, Colao A, Ferolla P, Wemeau JL, Caron P, Sadoul JL, Oneto A, Archambeaud F, Calender A, Sinilnikova O, Montanana CF, Cavagnini F, Hana V, Solano A, Delettieres D, Luccio-Camelo DC, Basso A, Rohmer V, Brue T, Bours V, Teh BT \& Beckers A. Aryl hydrocarbon receptorinteracting protein gene mutations in familial isolated pituitary adenomas: analysis in 73 families. Journal of Clinical Endocrinology and Metabolism 200792 1891-1896.

12 Georgitsi M, Raitila A, Karhu A, van der Luijt RB, Aalfs CM, Sane T, Vierimaa O, Mäkinen MJ, Tuppurainen K, Paschke R, Gimm O, Koch CA, Gündogdu S, Lucassen A, Tischkowitz M, Izatt L, Aylwin S, Bano G, Hodgson S, De Menis E, Launonen V, Vahteristo P \& Aaltonen LA. Germline CDKN1B/p27Kip1 mutation in multiple endocrine neoplasia. Journal of Clinical Endocrinology and Metabolism 200792 3321-3325.

13 Iwata T, Yamada S, Mizusawa N, Golam HM, Sano T \& Yoshimoto K. The aryl hydrocarbon receptor-interacting protein gene is rarely mutated in sporadic GH-secreting adenomas. Clinical Endocrinology 200766 499-502.

14 Toledo RA, Lourenco DM, Jr, Liberman B, Cunha-Neto MB, Cavalcanti MG, Moyses CB, Toledo SP \& Dahia PL. Germline mutation in the aryl hydrocarbon receptor interacting protein gene in familial somatotropinoma. Journal of Clinical Endocrinology and Metabolism 200792 1934-1937.

15 Bertherat J. Carney Complex (CNC). ORPHANET. www.orpha.net/ data/patho/GB/uk-CarneyComplex.pdf (Accessed June 19th, 2007).

16 Pellegata NS, Quintanilla-Martinez L, Siggelkow H, Samson E, Bink K, Hofler H, Fend F, Graw J \& Atkinson MJ. Germ-line mutations in p27Kip1 cause a multiple endocrine neoplasia syndrome in rats and humans. PNAS 2006103 15558-15563.

17 Georgitsi M, Raitila A, Karhu A, Tuppurainen K, Makinen MJ, Vierimaa O, Paschke R, Saeger W, van der Luijt RB, Sane T, Robledo M, De Menis E, Weil RJ, Wasik A, Zielinski G, Lucewicz O, Lubinski J, Launonen V, Vahteristo P \& Aaltonen LA. Molecular diagnosis of pituitary adenoma predisposition caused by aryl hydrocarbon receptor-interacting protein gene mutations. PNAS 2007104 4101-4105.

18 Ozawa A, Agarwal SK, Mateo CM, Burns AL, Rice TS, Kennedy PA, Quigley CM, Simonds WF, Weinstein LS, Chandrasekharappa SC, Collins FS, Spiegel AM \& Marx SJ. The parathyroid/pituitary variant of multiple endocrine neoplasia type 1 usually has causes other than p27Kip1 mutations. Journal of Clinical Endocrinology and Metabolism 200792 1948-1951.

19 Barlier A, Vanbellinghen JF, Daly AF, Silvy M, Jaffrain-Rea ML, Trouillas J, Tamagno G, Cazabat L, Bours V, Brue T, Enjalbert A \& Beckers A. Mutations in the aryl hydrocarbon receptor interacting protein gene are not highly prevalent among subjects with sporadic pituitary adenomas. Journal of Clinical Endocrinology and Metabolism 200792 1952-1955.

20 Gueorguiev M, Quinton R, Chapple R, Leontiou C, Lolli F, Wass JA, Popovic V, Ribeiro-Oliveira A, Gadelha MR, Clayton RN, Jordan S, Frohman LA, Grossman AB \& Korbonits M. The role of AIP in familial acromegaly. The Endocrine Society 89th Annual Congress 2007, 2007 OR15-2.

21 Stratakis CA, Matyakhina L, Courkoutsakis N, Patronas N, Voutetakis A, Stergiopoulos S, Bossis I \& Carney JA. Pathology and molecular genetics of the pituitary gland in patients with the 'complex of spotty skin pigmentation, myxomas, endocrine overactivity and schwannomas' (Carney complex). Frontiers of Hormone Research 200432 253-264.

22 Kovacs K, Horvath E, Thorner MO \& Rogol AD. Mammosomatotroph hyperplasia associated with acromegaly and hyperprolactinemia in a patient with the McCune-Albright syndrome. A histologic, immunocytologic and ultrastructural study of the surgicallyremoved adenohypophysis. Virchows Archives A, Pathological Anatomy and Histopathology 1984403 77-86.

23 de Oliveira SK, Hoffmeister M, Gambaryan S, Muller-Esterl W, Guimaraes JA \& Smolenski AP. Phosphodiesterase 2A forms a complex with the co-chaperone XAP2 and regulates nuclear translocation of the aryl hydrocarbon receptor. Journal of Biological Chemistry 2007282 13656-13663.

24 Bolger GB, Peden AH, Steele MR, MacKenzie C, McEwan DG, Wallace DA, Huston E, Baillie GS \& Houslay MD. Attenuation of the activity of the cAMP-specific phosphodiesterase PDE4A5 by interaction with the immunophilin XAP2. Journal of Biological Chemistry 2003278 33351-33363.

25 Kang BH \& Altieri DC. Regulation of survivin stability by the aryl hydrocarbon receptorinteracting protein. Journal of Biological Chemistry $200628124721-24727$.

26 Yano M, Terada K \& Mori M. AIP is a mitochondrial import mediator that binds to both import receptor Tom20 and preproteins. Journal of Cell Biology 2003163 45-56.

27 Hollingshead BD, Patel RD \& Perdew GH. Endogenous hepatic expression of the hepatitis $\mathrm{B}$ virus $\mathrm{X}$-associated protein 2 is adequate for maximal association with aryl hydrocarbon receptor90-kDa heat shock protein complexes. Molecular Pharmacology 200670 2096-2107.

28 Petersen SL, Krishnan S \& Hudgens ED. The aryl hydrocarbon receptor pathway and sexual differentiation of neuroendocrine functions. Endocrinology 2006147 S33-S42.

29 Den Hond E \& Schoeters G. Endocrine disrupters and human puberty. International Journal of Andrology 200629 264-271.

30 Beischlag TV \& Perdew GH. ER alpha-AHR-ARNT protein-protein interactions mediate estradiol-dependent transrepression of dioxin-inducible gene transcription. Journal of Biological Chemistry $200528021607-21611$.

31 Matthews J, Wihlen B, Thomsen J \& Gustafsson JA. Aryl hydrocarbon receptor-mediated transcription: ligand-dependent recruitment of estrogen receptor alpha to 2,3,7,8- tetrachlorodibenzo-p-dioxin-responsive promoters. Molecular Cell Biology 200525 5317-5328.

32 Fan M, Park A \& Nephew KP. CHIP (carboxyl terminus of Hsc70interacting protein) promotes basal and geldanamycin-induced degradation of estrogen receptor-alpha. Molecular Endocrinology $2005192901-2914$.

33 Morales JL \& Perdew GH. Carboxyl terminus of hsc70-interacting protein (CHIP) can remodel mature aryl hydrocarbon receptor (AhR) complexes and mediate ubiquitination of both the AhR and the $90 \mathrm{kDa}$ heat-shock protein (hsp90) in vitro. Biochemistry 2007 46 610-621.

34 Gioiosa L, Fissore E, Ghirardelli G, Parmigiani S \& Palanza P. Developmental exposure to low-dose estrogenic endocrine disruptors alters sex differences in exploration and emotional responses in mice. Hormones and Behaviour 200752 307-316.

35 Franczak A, Nynca A, Valdez KE, Mizinga KM \& Petroff BK. Effects of acute and chronic exposure to the aryl hydrocarbon receptor agonist 2,3,7,8-tetrachlorodibenzo-p-dioxin on the transition to reproductive senescence in female Sprague-Dawley rats. Biology of Reproduction 200674 125-130.

36 Gray LE Jr \& Ostby JS. In utero 2,3,7,8-tetrachlorodibenzo-p-dioxin (TCDD) alters reproductive morphology and function in female rat offspring. Toxicology and Applied Pharmacology 1995133 285-294.

37 Baba T, Mimura J, Nakamura N, Harada N, Yamamoto M, Morohashi K \& Fujii- Kuriyama Y. Intrinsic function of the aryl hydrocarbon (dioxin) receptor as a key factor in female reproduction. Molecular Cell Biology 200525 10040-10051. 
38 Merisalu A, Punab M, Altmae S, Haller K, Tiido T, Peters M \& Salumets A. The contribution of genetic variations of aryl hydrocarbon receptor pathway genes to male factor infertility. Fertility and Sterility 2007 In Press.

39 Tsuchiya M, Katoh T, Motoyama H, Sasaki H, Tsugane S \& Ikenoue T. Analysis of the AhR, ARNT, and AhRR gene polymorphisms: genetic contribution to endometriosis susceptibility and severity. Fertility and Sterility $2005 \mathbf{8 4} 454-458$.

40 Elango A, Shepherd B \& Chen TT. Effects of endocrine disrupters on the expression of growth hormone and prolactin mRNA in the rainbow trout pituitary. General and Comparative Endocrinology $2006145116-127$.

41 Gonzalez-Parra S, Argente J, Garcia-Segura LM \& Chowen JA. Cellular composition of the adult rat anterior pituitary is influenced by the neonatal sex steroid environment. Neuroendocrinology 1998 68 152-162.
42 Gonzalez-Parra S, Chowen JA, Garcia-Segura LM \& Argente J. In vivo and in vitro regulation of pituitary transcription factor-1 (Pit-1) by changes in the hormone environment. Neuroendocrinology 199663 3-15.

43 Rasier G, Toppari J, Parent AS \& Bourguignon JP. Female sexual maturation and reproduction after prepubertal exposure to estrogens and endocrine disrupting chemicals: a review of rodent and human data. Molecular and Cellular Endocrinology 2006255 187-201.

Received 27 June 2007

Accepted 21 August 2007 